\title{
Advances and Challenges in RNA Interference Technology for Citrus Huanglongbing Vector Control
}

\author{
Viviani Vieira Marques ${ }^{1}$, Jéssika Angelotti-Mendonça ${ }^{2}$ (D) and Sergio Ruffo Roberto ${ }^{3, *(D)}$ \\ 1 Arthur Bernardes Foundation/Embrapa Soybean, Biotechnology Laboratory, Carlos João Strass Road, District \\ of Warta, Londrina 86001-970, Brazil; vivianimarques@yahoo.com.br \\ 2 National Council for Scientific and Technological Development/Embrapa Soybean, Biotechnology Laboratory, \\ Carlos João Strass Road, District of Warta, Londrina 86001-970, Brazil; jangelottimendonca@gmail.com \\ 3 Agricultural Research Center, State University of Londrina, Celso Garcia Cid Road, km 380, \\ Londrina 86057-970, Brazil \\ * Correspondence: sroberto@uel.br; Tel.: +55-43-3371-4774
}

Citation: Marques, V.V.;

Angelotti-Mendonça, J.; Roberto, S.R.

Advances and Challenges in RNA

Interference Technology for Citrus

Huanglongbing Vector Control.

Horticulturae 2021, 7, 277. https:/ /

doi.org/10.3390/horticulturae7090277

Academic Editors: Douglas

D. Archbold and Yan Xu

Received: 28 June 2021

Accepted: 24 August 2021

Published: 2 September 2021

Publisher's Note: MDPI stays neutral with regard to jurisdictional claims in published maps and institutional affiliations.

Copyright: (c) 2021 by the authors. Licensee MDPI, Basel, Switzerland. This article is an open access article distributed under the terms and conditions of the Creative Commons Attribution (CC BY) license (https:// creativecommons.org/licenses/by/ $4.0 /)$

\begin{abstract}
Citrus species, including sweet oranges, grapefruits, pomelos, and lemons, are the most widely cultivated trees and consumed fruits worldwide. In citrus orchard management, the control of Huanglongbing (HLB) disease and its insect vector Diaphorina citri (Asian citrus psyllid, ACP) represents a major global challenge. Consumers have been increasingly pushing the citrus production chain toward a more sustainable system, including stringent measures to prevent the use of chemical pesticides. In recent years, biotechnological advances have offered safe and environmentally friendly alternatives for crop production. Technologies such as RNA interference (RNAi)-mediated gene silencing have emerged as innovative tools for agricultural pest management. Here, we provide an overview of RNAi as a promising approach for ACP control and discuss the associated challenges. Despite the availability of specific silencing sequences aimed at a target gene of the insect pest, the uptake of double-stranded RNA is limited in hemipteran insects. In this context, improved delivery methods, stability maintenance, and RNAi response are considered the factors contributing to the increased effectiveness of exogenous RNAi against hemipteran pests. These approaches can serve as potential tools for efficient ACP control.
\end{abstract}

Keywords: gene silencing; Huanglongbing; sweet orange; crop protection; sustainability

\section{Introduction}

Citrus juices act as the natural source of water, vitamins, minerals, sugars, acids, phytochemicals (e.g., polyphenols), and other organic compounds [1]. Owing to these characteristics, citrus species are the most popular fruit trees worldwide. In many countries, the citrus industry plays an important role in economic development, generating employment opportunities, increasing household income, and ultimately minimizing social inequality [2-5]. The conventional production methods of citrus fruits, such as oranges, mandarins, limes, and lemons, generate several products and by-products, which are primarily exported overseas [2].

Major obstacles in citrus tree development include weather conditions and disease epidemics. In particular, following its emergence, citrus Huanglongbing (HLB) disease has become the primary threat to citrus production in majority of the main global citrusproducing areas, including Brazil, the USA, and China [6-8].

HLB is caused by a Gram-negative bacterium of the genus Candidatus Liberibacter $[9,10]$ and spread by the insect vector Diaphorina citri Kuwayama (Hemiptera: Leviidae), also known as Asian citrus psyllid (ACP) [11]. Within the plant, the bacterium is restricted to the phloem and cannot be cultured in artificial media. Moreover, there are no effective tools to control the spread of the insect vector and no commercial citrus varieties resistant to HLB have been developed to date, which further hamper disease control [6-8]. 
Nonetheless, integrated management involving the cultivation of trees in certified protected nurseries, monitoring of ACP populations and citrus tree shoots, application of biological and chemical measures to control insect population, and rapid removal of symptomatic trees from the field has been implemented [6,11,12]. Insecticides are a critical component of ACP management [11]; however, as insects can develop resistance to insecticides over time, new chemicals and protein-based molecules with different modes of action are essential to maintain disease control efficiency and provide sustainable solutions. In this light, biotechnological tools developed during the last two decades have proven useful in agriculture to overcome the various challenges of pest resistance, disease spread, weed control, and stress tolerance and thereby improve product yield and quality [13]. For instance, RNA interference (RNAi) is based on the silencing of target gene expression through the intervention of double-stranded RNA (dsRNA) [13]. This technology has been tested as a novel approach in different eukaryotic species and, thanks to its high specificity, may serve as a potent tool for crop protection by managing insect pests or controlling the spread of vector-borne diseases [14-16]. RNAi presents great potential for ACP management because most of the core machinery genes are present in insects [17]. Therefore, insect control can be achieved through the cultivation of genetically modified citrus plants or application of dsRNA-based pesticides, similar to the conventional ones [18]. However, the second approach can be considered easier for application in the field from the perspective of different regulatory processes across countries. RNA-based pesticides can protect trees while reducing the use of chemicals to control ACP [19], serving as an effective yet sustainable agricultural technology [20]. Despite its many benefits, however, some challenges related to the use of RNAi for insect control remain. For instance, lack of an efficient method for the delivery of dsRNA to the insect action site, off-target and non-target analytical effects, potential development of resistance, and cost of dsRNA synthesis are some of the shortcomings of RNAi [21-23]. In this mini review, we discuss the recent advances and major challenges in RNAi tools for ACP control.

\section{RNAi Machinery}

In RNAi, an RNA molecule inhibits mRNA translation, thus hindering protein synthesis [24]. Fire et al. [13] first described RNAi using dsRNA-mediated gene silencing in the nematode Caenorhabditis elegans. Briefly, once inside the cells, the dsRNA is cleaved by endonuclease III DICER into a small interfering RNA (siRNA) of 20-23 nucleotides. Then, the double-stranded siRNA is separated, and the guide strand binds to the Argonaute (AGO) protein, forming the catalytic component of the RNA-induced silencing complex (RISC) [24]. Next, the siRNA-AGO complex recruits other components of RISC and mediate mRNA degradation, mRNA translational repression, or chromatin modification, leading to post-transcriptional gene silencing (PTGS) [24].

The systemic effects of RNAi are essential for the practical application of RNAimediated silencing in pest and pathogen management. One of the pathways of systemic RNAi effects involves secondary dsRNA synthesis from the remaining mRNA molecule or the passenger strand of siRNA through the activity of RNA-dependent RNA polymerases (RdRPs) [25]. This secondary source of dsRNA has been reported in most eukaryotes, including plant pathogens and pests. However, no RdRP orthologs have been detected in hemipterans, suggesting that secondary dsRNA synthesis does not occur in these insects and that they present another as yet unreported system that amplifies dsRNA synthesis [16]. Although the precise mechanism underlying the amplification dsRNA synthesis remains unknown, several studies have reported the success of RNAi-mediated silencing in hemipterans, including ACP. Given that these insects harbor the core components of the RNAi machinery, namely DICER and AGO family proteins, RNAi-mediated gene silencing may indeed be used to manage ACP [26]. 


\section{Challenges in RNAi-Mediated Silencing for Pest Control}

RNAi-mediated silencing is a promising tool for pest control. However, for efficient dsRNA action in insects, the molecule must be taken up by the intestinal lumen and come in contact with the interior of the cell, where it can trigger PTGS [16]. However, certain challenges are involved in the uptake of dsRNA and activation of RNAi machinery, such as the dsRNA delivery method, dsRNA concentration, dsRNA nucleotide sequence and length, dsRNA persistence inside the insect body, and developmental stage of the insect.

\subsection{IsRNA Uptake and Spread into the Insect Body}

dsRNA can be taken up through two mechanisms: cell-autonomous and non-cellautonomous. In the cell-autonomous mechanism, dsRNA-triggered silencing is restricted to the cells in which the dsRNA is introduced or expressed. This mechanism is the most common RNAi pathway and involves the cleavage of dsRNA into siRNA through RISC to induce PTGS [24]. In the non-cell-autonomous mechanism, dsRNA-triggered silencing occurs in cells or tissues different from those where the dsRNA is introduced or synthesized. The non-cell-autonomous mechanism involves environmental and systemic RNAi. Environmental RNAi refers to all mechanisms through which dsRNA is absorbed by the cell directly from the surrounding environment (eRNA) [27,28], while systemic RNAi involves the transport of dsRNA molecules from one tissue or cell to another, occurring exclusively in multicellular organisms $[29,30]$.

The internalization of dsRNA/siRNA by cells is essential for RNAi-mediated silencing in insects. If dsRNA is taken up via ingestion, the molecules must pass through the peritrophic matrix before being internalized by the midgut epithelia and bind to lipophorins in the hemolymph [31]. The systemic effect of RNAi-mediated silencing is not well known in insects, although it has been well documented in the nematode C. elegans [30].

The injection of dsRNA into C. elegans gut lumen can allow for the determination of whether the dsRNA/siRNA is spread throughout the cell via the action of systemic RNA interference deficient-1 (SID-1). SID-1 is a transmembrane protein that acts as a channel for dsRNA uptake via diffusion, and this protein is present in all cells sensitive to RNAimediated silencing $[29,30,32]$. Although the systemic effect of RNAi is SID-1-dependent, dsRNA uptake is SID-2-dependent. SID-2 is a transmembrane-like-protein localized in the gut lumen cells of animals. This protein is important for the incorporation of RNA from the environment into the organism but plays no role in the transport of the endogenous molecules [28]. Thus, SID-1 and SID-2 proteins or their orthologs are essential for RNAi systemic effects and dsRNA uptake from the environment, respectively, enabling gene silencing $[28,29,32]$. SID-1 protein homologs have been reported in several insect species, such as the red flour beetle (Tribolium castaneum), silkworm (Bombyx mori), European honey bee (Apis mellifera), aphids (Myzus persicae) [33], and ACP [26].

Hemipterans, coleopterans, dipterans, and orthopterans lack SID homologs, and dsRNA uptake in these insects likely occurs through receptor-mediated clathrin-dependent endocytosis. In this mechanism, dsRNA is internalized via the action of a scavenger receptor [31]. In T. castaneum, despite the presence of SID protein homologs, endocytosis is the major pathway of dsRNA uptake. In this mechanism, dsRNA first binds to unknown receptor proteins in the plasma membrane. The resulting complex, called AP-2, interacts with clathrin to form a clathrin-coated vesicle, which fuses to an endosome. Before the fusion of the late endosome to a lysosome, dsRNA molecules are released into the cytosol, where they trigger the RNAi core machinery $[31,34,35]$. Thus, the endocytotic mechanism of dsRNA uptake may promote RNAi-mediated gene silencing in organisms. In ACP, the core components of clathrin-mediated endocytosis, namely the clathrin heavy chain and AP50, an AP-2-like protein, have been identified [17].

\section{2. dsRNA Delivery}

dsRNA can be delivered into ACP through several means, and the primary delivery methods can be divided into transformant and non-transformant methods (Figure 1) [36]. 
The transformant method involves the generation of a transgenic plant (genetically modified organism, GMO) harboring a construct to produce dsRNA targeting the insect mRNA. Meanwhile, the non-transformant delivery methods are GMO-free and include micro-injection of dsRNA directly into the hemolymph [37], topical application on insect body $[38,39]$, soaking insects into a dsRNA solution $[40,41]$, feeding insects with artificial diets containing dsRNA molecules [42-44], and feeding insect with plants treated with a dsRNA solution through drenching or trunk injection [45]. Despite the introduction of several dsRNA molecules, however, only those delivery methods that result in insect topical absorption and/or acquisition via feeding are applicable for ACP management in citrus orchards (Table 1). Thus, the most suitable dsRNA delivery methods for ACP control involve foliar spray, root absorption via irrigation water, and ingestion of GMO plants expressing dsRNA for insect target gene silencing [46].

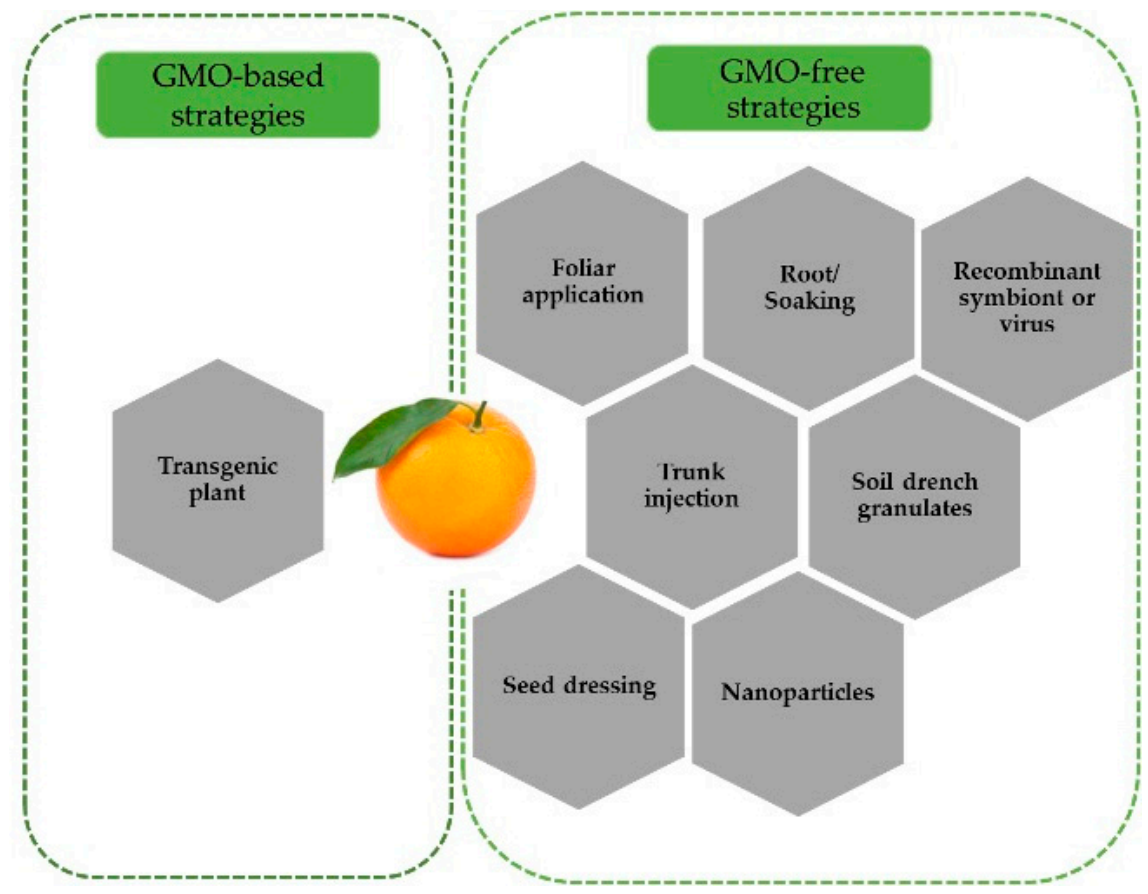

Figure 1. Novel approaches to RNA interference (RNAi)-mediated insect control—delivery strategies. GMO-based strategies: use of genetically modified plants is the best-known approach to RNAi-based control of insect pests or vectors. GMO-free strategies: specific genes of target in an insect are silenced using novel approaches.

However, the dsRNA delivery methods involving topical absorption and ingestion present some additional challenges, because in both approaches, the dsRNA molecules must overcome additional barrier mechanisms expressed by the insects to prevent the internalization of the molecules in cells. For instance, in topical application, the dsRNA must pass through the covering ACP tissues, penetrating the cuticle layers, until reaching the epidermis cells [47]. In dsRNA delivery methods relying on absorption during the feeding period, the dsRNA molecules must remain stable under the conditions of the gut long enough to be absorbed into the epithelium cells and must be transported throughout the insect body, taken up in distant cells, and then processed or used to suppress complementary mRNAs $[31,48]$. In some hemipteran pests, oral delivery is confounded by high ribonuclease activity in the saliva, which degrades dsRNA [49].

Additionally, the delivery methods that involve dsRNA acquisition via ingestion are associated with the additional challenges of the availability of dsRNA or siRNA in GMOs at amounts sufficient to trigger RNAi-mediated silencing response [35]. In GMOs, majority of the dsRNA molecules delivered are siRNAs, which may affect the stability of the molecules inside the insect body, as smaller molecules are more easily degraded by nucleases in the 
midgut [27,50-52]. In contrast, non-transformant methods only involve the acquisition of longer dsRNA by insects [27]. Nonetheless, hemipterans, such as ACP, are sap-sucking insects, and the dsRNA must be available at sufficient amounts in the tissues on which the insects mainly feed, such as the phloem. Thus, for ACP control, dsRNA delivery methods should provide dsRNA molecules into the phloem vessels.

Table 1. Asian citrus psyllid (ACP, Diaphorina citri) control via RNAi technology.

\begin{tabular}{|c|c|c|c|c|c|}
\hline Target Gene & $\begin{array}{l}\text { Gene Target } \\
\text { Function }\end{array}$ & $\begin{array}{l}\text { dsRNA } \\
\text { Delivery }\end{array}$ & $\begin{array}{c}\text { Developmental } \\
\text { Stage }\end{array}$ & Result & Reference \\
\hline $\begin{array}{c}\text { Abnormal wings disc } \\
\text { (awd) }\end{array}$ & $\begin{array}{l}\text { Essential for adult wing } \\
\text { formation }\end{array}$ & $\begin{array}{c}\text { Topical } \\
\text { application }\end{array}$ & $\begin{array}{l}\text { Fifth instar } \\
\text { nymphs }\end{array}$ & $\begin{array}{l}\text { Increased nymph } \\
\text { mortality and } \\
\text { abnormal wing } \\
\text { development in } \\
\text { adults }\end{array}$ & [53] \\
\hline $\begin{array}{l}\text { Cytochrome P450 gene } \\
\text { family } 4 \text { (CYP4) }\end{array}$ & $\begin{array}{l}\text { Detoxifying enzyme } \\
\text { related to insecticide } \\
\text { resistance }\end{array}$ & $\begin{array}{c}\text { Topical } \\
\text { application }\end{array}$ & Adults & $\begin{array}{c}\text { Increased } \\
\text { insecticide } \\
\text { susceptibility }\end{array}$ & {$[54]$} \\
\hline Arginine kinase & Energy mobilization & In plant system & Adults & $\begin{array}{l}\text { Increased adult } \\
\text { mortality }\end{array}$ & \multirow{5}{*}{ [26] } \\
\hline $\begin{array}{c}\text { Superoxide dismutase } \\
\text { (SOD) }\end{array}$ & Antioxidant defense & In plant system & Adults & $\begin{array}{l}\text { Increases adult } \\
\text { mortality }\end{array}$ & \\
\hline $\begin{array}{c}\text { Pterin-4-alpha- } \\
\text { carbinolamine } \\
\text { dehydratase }(P C D B 1)\end{array}$ & Cell metabolism & In plant system & Adults & None & \\
\hline Tomosyn & Nervous system & In plant system & Adults & None & \\
\hline Vitellogenin & Reproduction & In plant system & Adults & None & \\
\hline Cathepsin D & Metamorphic events & $\begin{array}{l}\text { Ingestion through } \\
\text { artificial diet and } \\
\text { in plant system }\end{array}$ & $\begin{array}{l}\text { Adults and fifth } \\
\text { instar nymphs }\end{array}$ & $\begin{array}{l}\text { Increased insect } \\
\text { mortality }\end{array}$ & \multirow{3}{*}{ [55] } \\
\hline Chitin synthase & Chitin synthesis & $\begin{array}{l}\text { Ingestion through } \\
\text { artificial diet and } \\
\text { in plant system }\end{array}$ & $\begin{array}{l}\text { Adults and fifth } \\
\text { instar nymphs }\end{array}$ & $\begin{array}{l}\text { Increased insect } \\
\text { mortality }\end{array}$ & \\
\hline Inhibitor of apoptosis & $\begin{array}{l}\text { Regulation of the } \\
\text { apoptotic machinery }\end{array}$ & $\begin{array}{l}\text { Ingestion through } \\
\text { artificial diet and } \\
\text { in plant system }\end{array}$ & $\begin{array}{l}\text { Adults and fifth } \\
\text { instar nymphs }\end{array}$ & $\begin{array}{l}\text { Increased insect } \\
\text { mortality }\end{array}$ & \\
\hline $\begin{array}{c}\text { Esterase FE4-like } \\
\text { (EstFE4); } \\
\text { acetylcholinesterase } \\
\text { (AChe) }\end{array}$ & $\begin{array}{l}\text { Detoxifying enzyme } \\
\text { related to insecticide } \\
\text { resistance }\end{array}$ & $\begin{array}{l}\text { Topical } \\
\text { feeding }\end{array}$ & $\begin{array}{l}\text { Fourth and fifth } \\
\text { instar nymphs }\end{array}$ & $\begin{array}{l}\text { Increased mortality } \\
\text { of nymphs and, } \\
\text { consequently, of } \\
\text { emerged adults }\end{array}$ & [56] \\
\hline $\begin{array}{l}\text { Muscle protein } 20 \\
(\text { DcMP20) }\end{array}$ & $\begin{array}{c}\text { Encodes a } \\
\text { cytoskeletal protein }\end{array}$ & Soaking & $\begin{array}{l}\text { Third and fourth } \\
\text { instar nymphs }\end{array}$ & $\begin{array}{l}\text { Increased nymph } \\
\text { mortality }\end{array}$ & {$[41]$} \\
\hline $\begin{array}{l}\text { Abnormal wings disc } \\
(a w d)\end{array}$ & $\begin{array}{l}\text { Essential for adult wing } \\
\text { formation }\end{array}$ & $\begin{array}{l}\text { Topical } \\
\text { feeding }\end{array}$ & $\begin{array}{l}\text { Adults and fifth } \\
\text { instar nymphs }\end{array}$ & $\begin{array}{l}\text { Increased nymph } \\
\text { mortality and } \\
\text { deformed adults }\end{array}$ & [39] \\
\hline Boule & Fertility & $\begin{array}{l}\text { Feeding in } \\
\text { artificial diet }\end{array}$ & Adults & $\begin{array}{l}\text { Increased adult } \\
\text { mortality, but no } \\
\text { effect on number } \\
\text { of eggs }\end{array}$ & [42] \\
\hline $\begin{array}{l}\text { Sucrose hydrolase } \\
\text { (DcSuh) }\end{array}$ & $\begin{array}{l}\text { Enhanced absorption of } \\
\text { sucrose from the } \\
\text { midgut }\end{array}$ & $\begin{array}{c}\text { Topical } \\
\text { application }\end{array}$ & $\begin{array}{l}\text { Fifth instar } \\
\text { nymphs }\end{array}$ & $\begin{array}{l}\text { Increased nymph } \\
\text { mortality and } \\
\text { shortened insect } \\
\text { lifecycle duration }\end{array}$ & [38] \\
\hline
\end{tabular}


Table 1. Cont.

\begin{tabular}{|c|c|c|c|c|c|}
\hline Target Gene & $\begin{array}{l}\text { Gene Target } \\
\text { Function }\end{array}$ & $\begin{array}{l}\text { dsRNA } \\
\text { Delivery }\end{array}$ & $\begin{array}{c}\text { Developmental } \\
\text { Stage }\end{array}$ & Result & Reference \\
\hline Laccase-1-S & $\begin{array}{c}\text { Detoxification of } \\
\text { secondary plant } \\
\text { compounds in insects }\end{array}$ & In plant system & Adults & None & \multirow{3}{*}{ [57] } \\
\hline DcSnf7 & $\begin{array}{l}\text { Transport of proteins } \\
\text { for degradation via the } \\
\text { endosomal autophagic } \\
\text { pathway }\end{array}$ & In plant system & Adults & None & \\
\hline Calreticulin & $\begin{array}{l}\text { Calcium ion chelation, } \\
\text { which helps maintain } \\
\text { phloem } \\
\text { circulation }\end{array}$ & In plant system & Adults & None & \\
\hline $\begin{array}{c}\text { Trehalose-6-phosphate } \\
\text { synthase }\end{array}$ & $\begin{array}{l}\text { Energy synthesis; } \\
\text { metamorphosis }\end{array}$ & $\begin{array}{l}\text { Feeding in } \\
\text { artificial diet }\end{array}$ & $\begin{array}{l}\text { Fifth instar } \\
\text { nymphs }\end{array}$ & $\begin{array}{l}\text { Increased nymph } \\
\text { mortality and } \\
\text { deformed adults }\end{array}$ & [43] \\
\hline Odorant-binding 7 & $\begin{array}{l}\text { Host plant volatile } \\
\text { compound } \\
\text { recognition }\end{array}$ & $\begin{array}{l}\text { Ingestion through } \\
\text { artificial diet }\end{array}$ & Adults & $\begin{array}{l}\text { Suppressed electro- } \\
\text { physiological } \\
\text { responses of } \\
\text { antennae and } \\
\text { disrupted insect } \\
\text { behavioral } \\
\text { responses }\end{array}$ & [44] \\
\hline
\end{tabular}

Currently, in RNAi experiments with ACP, the so-called "in plant systems" (iPS) are commonly used to deliver dsRNA into psyllids via feeding [15]. This delivery method involves the use of a detached leaf that absorbs a solution containing the dsRNA for gene silencing in insects via the petiole. Although this method with a Cy3-labeled dsRNA has been successfully used by Taning et al. and Galdeano et al. [26,55], Angelotti-Mendonça et al. [57] demonstrated that most of the dsRNA absorbed by the detached leaves remained in the xylem. Because ACP mainly feeds on sap in the phloem and only derives water from the xylem, the insects likely ingested only a small amount of dsRNA from the xylem. Thus, iPS is not suitable to silence the target candidate genes in ACP using RNAi. Moreover, this method does not properly simulate dsRNA application methods, such as drenching or foliar spray. For instance, in citrus nursery trees, dsRNA delivery through drenching resulted in dsRNA absorption by roots and its spread to other plant tissues, including phloem, as evidenced by the detected of labeled dsRNA in the xylem and phloem. Additionally, dsRNA molecules were detected in the vessel tissues of new shoots and leaves of the treated citrus nursery trees 3 days after the treatment, indicating that dsRNA delivery through irrigation water may be suitable for ACP control in citrus orchards, because a large amount of dsRNA was detected in the phloem [58].

The most common method to deliver pesticides is through foliar spray; however, the application of this method to deliver dsRNA for the control of sap-sucking insects involves additional challenges. In this method, the insect may take up dsRNA molecules through contact, similar to soaking or topical application, or via feeding on plants. Following the absorption and spread of dsRNA molecules to the phloem vessel tissues, they must remain stable for the required period and be available at amounts sufficient to trigger silencing until they are consumed by the insects. Additionally, in foliar spray, the translocation and uptake of dsRNA must overcome several barriers, such as passing through the leaf cuticle, degradation by nucleases until absorption by the vegetal cells, and spreading into phloem vessel tissue [59]. 


\section{3. dsRNA Stability and Efficiency}

The stability and efficiency of RNAi for gene silencing in insects may drastically vary depending on the concentration or dose and the length or size of the dsRNA, application method, delivery technique, plant organospecific processes, adverse environmental conditions, insect life stage, and choice of the target gene to be silenced $[19,60]$.

For most insects, the results of dsRNA injection delivery differed from those of the other delivery methods. dsRNA injection enables the delivery of a precise amount of dsRNA directly into the target tissues or the hemolymph, consequently achieving a high level of gene silencing $[17,56,61]$. The first contact before cellular uptake is either the hemolymph or the gut content [31], and these body fluids may act as the main causes of dsRNA instability due to the enzymatic activity of double-stranded ribonucleases (dsRNases) and the physiological pH driving enzymatic activity in these fluids [31,35]. Additionally, the lack of functional RNAi machinery and availability of limited knowledge on dsRNA uptake, transport, and systemic propagation mechanisms contribute to this instability [35]. The ACP genome harbors three dsRNase homologs, and dsRNA degradation due to high $\mathrm{pH}$ and/or dsRNase action in the gut and salivary secretions has already been confirmed [15]. Recently, dsRNA degradation was confirmed when a high dsRNA dose was required to suppress the expression of the DcBol fertile gene [17,42].

Some strategies have already been developed to address issues related to dsRNA instability. As such, nanotechnological applications can significantly enhance the efficiency of agricultural inputs, such as plant growth promoters, nano-pesticides, nano-fertilizers, nanoherbicides, agrochemicals, and RNAi-based pesticides [62]. The nanoparticle-mediated dsRNA delivery system has been used to improve the persistence, penetration, and transport of RNAi molecules into plants or insects [35,63].

Nanoparticles are matter particles ranging in diameter between 1 and $100 \mathrm{~nm}$. Advantages of using chitosan, liposomes, and cationic dendrimers as nanoparticles for protecting and delivering dsRNA/siRNA to improve RNAi efficiency and thus promote the development and practice of RNAi-based pest management strategies have already been documented [61]. In addition, in recent years, carbon-based nanomaterials, such as carbon nanotubes, and the structure-property-cytotoxicity interplay of other nanoparticles, such as quantum dots and graphene oxide, have been investigated [64,65].

Recently, the combination of RNAi and nanotechnology was demonstrated efficient in increasing the stability and efficacy of dsRNA in RNAi-mediated bed bugs control [66]. For bed bugs, the use of a long dsRNA elicited a silencing response; however, a high dosage was required to obtain a similar response in other insects, such as coleopterans [67]. This difference may be related to taxon-specific RNAi response. In coleopterans, an orally delivered long dsRNA ( $\geq 200-500$ nucleotides) is processed into the cell to yield siRNAs, which ultimately trigger mRNA degradation [66]. The dsRNA fragment size may be reduced to avoid off-target silencing [68,69]. In addition, protection by nanoparticles increased the efficiency of RNAi action in Euchistos heros [66]. To trigger RNAi in E. heros, short hairpin RNA (shRNA) was orally delivered using cerium oxide nanoparticles $(4 \mathrm{~nm})$ coated with diethylamioethyl dextran (as the carrier. The particle properties and shRNA loading rates (Ce:shRNA mass ratio) resulted in successful transcript reduction or RNAi. Significant mortality attributed to RNAi was observed at the shRNA concentration of $250 \mathrm{ng} \cdot \mu \mathrm{L}^{-1}$ in the feeding solution. The degradation of the targeted troponin transcript via nanoparticle-delivered shRNA was equivalent to that observed with a long dsRNA, although naked shRNA transcript reduction was not statistically significant [66].

Nonetheless, these nanoparticle-based RNA pesticides must be simple and the required raw materials should be affordable for low-cost production [61,70]. In addition, application dsRNA-based pesticides through either irrigation or foliar spray must be explored [68] to promote their oral uptake by insects via feeding [15].

Although nano-formulations are in high demand in the pesticide industry, there is little information on the environmental risks associated with nanoparticle-based RNA 
pesticides, and further research is on the environmental impact assessment of nanotools is warranted [61,71].

\subsection{Off-Targets}

With accumulating knowledge on the RNAi machinery, novel approaches using this technique have been elucidated and developed every year $[18,19,31,60,72,73]$. siRNAs of approximately 21-25 nucleotides are the key intermediaries in triggering sequence-specific RNA degradation during PTGS in invertebrates [72]. These sequence specificities minimize any detrimental effects of RNAi on non-target organisms (NTOs) [74].

In recent years, there has been significant development in bioinformatic software to assess the potential hazards of RNAi. Software have been developed to optimize the RNAi design to ensure specific target gene knockdown [75]. To date, however, there are methods to quantify the reliability of these bioinformatic software in assessing such off-target effects. Given the variability in environmental exposure, barriers to systemic exposure, and differences in RNAi machinery among organisms, the bioinformatic software as the sole tool is not recommended $[74,76,77]$. Specialists from the academic, industrial, and government sectors have discussed several aspects of RNAi, with particular focus on furthering our knowledge of the technology for risk assessment $[18,78]$. The conference held by the Organization for Economic Cooperation and Development covered multiple perspectives related to RNAi-based pesticides. The potential exposure of NTOs and responsiveness to environmental RNAi have been discussed as the main parameters to be considered in the risk assessment of exogenous dsRNA application, and appropriate legislation involving risk assessment procedures in science-based topical RNAi-based applications must be enacted (Figure 2) [76].
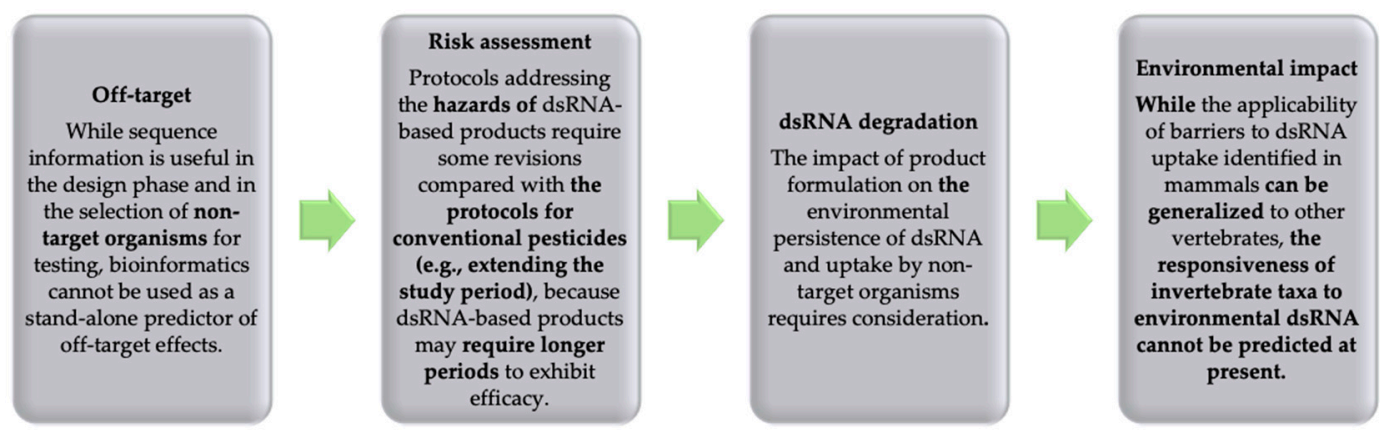

Figure 2. Key aspects and considerations related to the use of RNAi-based pesticides discussed at the conference held by the Organization for Economic Cooperation and Development (OECD) (adapted from Mendelsohn et al. [76]).

A recent study evaluated the activity of three specific dsRNA molecules targeting genes in different insects, representing the classic biocontrol agents of the emerald ash borer (EAB, Agrilus planipennis) in some countries. The study provided substantial data to demonstrate the feasibility of using novel alternatives for EAB management that are ecofriendly and safe for NTOs [74].

\section{ACP Control Using RNAi Technology}

Since the first report of the use of RNAi-mediated gene silencing for pest control [79,80], the application of this technology has been extensively studied for the control of insects, including ACP. Indeed, the success of this technology depends on several factors that affect the dsRNA delivery method, and target gene selection is crucial. Several studies on the RNAi-mediated control of ACP are summarized in Table 1. Additional factors including the characteristics of the dsRNA molecule, such length and concentration, must also be appropriately adjusted to ensure pesticide effectiveness.

Initial studies on the RNAi-mediated control of ACP focused on the delivery of dsRNA via topical application. In the first study using dsRNA, the abnormal wing disc (awd) gene, 
which is essential for adult wing formation, was successfully silenced through topical dsRNA application in fifth instar nymphs, leading to wing deformation and flight arrest in adults [53]. Successful silencing of several target genes at different insect developmental stages using various dsRNA delivery methods has been tested (Figure 1).

RNAi-mediated ACP control has also been tested using feeding assays. Through the ingestion of an artificial diet, several genes including cathepsin $D$, chitin synthase, inhibitor of apoptosis [55], boule [42], trehalose-6-phosphate synthase [43], and odorant-binding 7 [44], in $\mathrm{ACP}$ were silences, leading to a lethal phenotype and/or an abnormal behavioral response. Furthermore, knockdown of the arginine kinase and superoxide dismutase genes through feeding and $i P S$ reduced the ACP adult survival rate [26]. In some other studies, despite successful gene silencing using $i P S$, however, dsRNA delivery through this method did not affect the insect survival rate or the expression of pterin-4- $\alpha$-carbinolamine dehydratase, tomosyn, vitellogenin [26], laccase-1S, calreticulin, and Snf7 [57]. These contrasting results suggest that the RNAi-mediated ACP control also depends on target selection. Additionally, successful Snf7 silencing in Western corn rootworm (Diabrotica virgivera) [81] and lack of effect in ACP indicate that silencing of a target gene in one organism does not necessarily work in others.

The dsRNA characteristics and delivery methods as well as the developmental stage of the insect treated with dsRNA can directly affect RNAi-mediated gene silencing. In general, hemipterans present stronger ribonuclease action at the adult stage, leading to higher dsRNA degradation and greater insect resistance when the dsRNA is delivered through oral ingestion [35,82-84]. In ACP, the early developmental stages (e.g., nymphs) exhibit greater sensitivity to RNAi than the later developmental stages (e.g., adults) [41]. Indeed, topical dsRNA application resulted in successful target silencing of the awd gene [53]. In addition, the mortality of third and fourth instar nymphs increased after soaking them in a dsRNA solution targeting muscle protein 20 (DcMP20) [41]. In addition, at the juvenile stages, topical dsRNA application resulted in the silencing of sucrose hydrolase (DcSuh), which reduced survival rate of the fifth instar nymphs and shortened the insect lifecycle duration [38]. Therefore, the application of RNAi-mediated control at the early developmental stages of ACP is essential for HLB management in citrus orchards. The fourth and fifth instar nymphs of ACP can spread the causal agent of HLB and increase the disease transmission, by spreading the pathogen as both nymphs and adults [85].

In addition to the development stage, the potential targets must be differentiated for a specific insect stage. Moreover, knowledge of the biological interactions with the host is essential to increase the efficiency of silencing of the candidate genes and, particularly, to ensure the reproducibility of the technology in the field. For instance, a recent study explored the molecular mechanism of the reproductive strategy of ACP. The fecundity and ovarian morphology of females confined to young shoots and mature citrus tissues were evaluated. In ACPs feeding on young shoots, psyllid female ovarian development was activated, inducing oviposition. However, silencing of the positive regulatory gene DcRheb in the target of rapamycin (TOR) pathway lowered ecdysone and juvenile hormone levels, suppressed vitellogenin synthesis, and reduced female reproductive capacity [86]. Genes in the TOR pathway, among others, have been proposed as the potent candidates for silencing to reduce the reproductive capacity of insects; however, if product of choice is an RNAi-based pesticide, it must be applied to shoots for successfully silencing the target transcripts.

\section{Primary Considerations and Future Prospects of RNAi Strategies for ACP Control in Citrus Orchards}

RNAi can serve as a potentially biosafe strategy to manage ACP. It can help control this insect pest through two modes of application: non-transformative (bioproduct) and transformative (transgenic plants) delivery. The non-transformative delivery presents some advantages for use in pest management because of the rapid product development, low cost, low resistance risk, and high viability for all crops [87], although there are no stringent regulations in different countries [88]. 
In this context, innovation systems in food and agriculture actively seek to go beyond the financial targets [89]. Building a more sustainable citrus industry for the future is essential to conserve the environment as well as respond to the demands of the food sector, which are increasingly focused on the environmental and social aspects. Therefore, exploiting cutting-edge technologies such as RNAi is essential to reduce the use of pesticides in orchards, thus generating minimal environmental impacts [35] and avoiding adverse effects on NTOs, such as pollinators. Finally, investment in scientific research is increasingly playing a relevant and significant role in promoting the citrus industry and ensuring that citrus growers continue to supply good quality fruits to the consumers and processors, overcoming the most relevant challenges in cultivation [2].

Author Contributions: V.V.M. contributed to writing, reviewing, and editing this review article. J.A.-M. contributed to writing. S.R.R. contributed to reviewing, and editing. All authors have read and agreed to the published version of the manuscript.

Funding: This research received no external funding.

Institutional Review Board Statement: Not applicable.

Informed Consent Statement: Not applicable.

Data Availability Statement: Data are contained within the article.

Conflicts of Interest: The authors declare no conflict of interest.

\section{References}

1. Rampersaud, G.C.; Valim, M.F. 100\% Citrus juice: Nutritional contribution, dietary benefits, and association with anthropometric measures. Crit. Rev. Food Sci. Nutr. 2017, 57, 129-140. [CrossRef]

2. Neves, M.F.; Trombin, V.G.; Marques, V.N.; Martinez, L.F. Global orange juice market: A 16-year summary and opportunities for creating value. Trop. Plant Pathol. 2020, 45, 166-174. [CrossRef]

3. Chavan, P.; Singh, A.K.; Kaur, G. Recent progress in the utilization of industrial waste and by-products of citrus fruits: A review. J. Food Process Eng. 2018, 41, 1-10. [CrossRef]

4. Spreen, T.H.; Zansler, M.L. Economic analysis of incentives to plant citrus trees in Florida. HortTechnology 2016, 26, 720-726. [CrossRef]

5. Ozkan, B.; Akcaoz, H.; Karadeniz, F. Energy requirement and economic analysis of citrus production in Turkey. Energy Convers. Manag. 2004, 45, 1821-1830. [CrossRef]

6. Bassanezi, R.B.; Lopes, S.A.; de Miranda, M.P.; Wulff, N.A.; Volpe, H.X.L.; Ayres, A.J. Overview of citrus Huanglongbing spread and management strategies in Brazil. Trop. Plant Pathol. 2020, 45, 251-264. [CrossRef]

7. Graham, J.; Gottwald, T.; Setamou, M. Status of Huanglongbing (HLB) outbreaks in Florida, California and Texas. Trop. Plant Pathol. 2020, 45, 265-278. [CrossRef]

8. Zhou, C. The status of citrus Huanglongbing in China. Trop. Plant Pathol. 2020, 45, 279-284. [CrossRef]

9. Bové, J.M. Huanglongbing: A destructive, newly-emerging, century-old disease of citrus. J. Plant Pathol. 2006, 88, 7-37.

10. Zheng, Z.; Chen, J.; Deng, X. Historical perspectives, management, and current research of citrus HLB in Guangdong province of China, where the disease has been endemic for over a hundred years. Phytopathology 2018, 108, 1224-1236. [CrossRef] [PubMed]

11. Qureshi, J.A.; Kostyk, B.C.; Stansly, P.A. Insecticidal suppression of Asian citrus psyllid Diaphorina citri (Hemiptera: Liviidae) vector of Huanglongbing pathogens. PLoS ONE 2014, 9, e112331. [CrossRef] [PubMed]

12. Belasque, J., Jr.; Yamamoto, P.T.; de Miranda, M.P.; Bassanezi, R.B.; Ayres, A.J.; Bové, J.M. Controle do Huanglongbing no estado de São Paulo, Brasil. Citrus Res. Technol. 2010, 31, 53-64. [CrossRef]

13. Fire, A.; Xu, S.; Montgomery, M.K.; Kostas, S.A.; Driver, S.E.; Mello, C.C. Potent and specific genetic interference by doublestranded RNA in Caenorhabditis Elegans. Nature 1998, 391, 806-811. [CrossRef] [PubMed]

14. Liu, S.; Jaouannet, M.; Dempsey, D.A.; Imani, J.; Coustau, C.; Kogel, K.H. RNA-based technologies for insect control in plant production. Biotechnol. Adv. 2020, 39. [CrossRef] [PubMed]

15. Andrade, E.C.; Hunter, W.B. RNAi feeding bioassay: Development of a non-transgenic approach to control Asian citrus psyllid and other hemipterans. Entomol. Exp. Appl. 2017, 162, 389-396. [CrossRef]

16. Huvenne, H.; Smagghe, G. Mechanisms of dsRNA uptake in insects and potential of RNAi for pest control: A review. J. Insect Physiol. 2010, 56, 227-235. [CrossRef]

17. Yu, X.; Killiny, N. RNA interference-mediated control of Asian citrus psyllid, the vector of the Huanglongbing bacterial pathogen. Trop. Plant Pathol. 2020, 45, 298-305. [CrossRef]

18. Alamalakala, L.; Parimi, S.; Patel, N.; Char, B. Insect RNAi: Integrating a new tool 10 in the crop protection toolkit. In Trends in Insect Molecular Biology and Biotechnology; Kumar, D., Gong, C., Eds.; Springer: Cham, Switzerland, 2018; ISBN 978-3-319-61343-7. 
19. Zhang, J.; Khan, S.A.; Heckel, D.G.; Bock, R. Next-generation insect-resistant plants: RNAi-mediated crop protection. Trends Biotechnol. 2017, 35, 871-882. [CrossRef]

20. Fletcher, S.J.; Reeves, P.T.; Hoang, B.T.; Mitter, N. A Perspective on RNAi-based biopesticides. Front. Plant Sci. 2020, 11, 1-10. [CrossRef]

21. Zhu, K.Y.; Palli, S.R. Mechanisms, applications, and challenges of insect RNA interference. Annu. Rev. Entomol. 2020, 65, $293-311$. [CrossRef]

22. Nehela, Y.; Killiny, N. Revisiting the complex pathosystem of Huanglongbing: Deciphering the role of citrus metabolites in symptom development. Metabolites 2020, 10, 409. [CrossRef] [PubMed]

23. Flynt, A.S. Insecticidal RNA interference, thinking beyond long dsRNA. Pest Manag. Sci. 2021, 77, 2179-2187. [CrossRef] [PubMed]

24. Meister, G.; Tuschl, T. Mechanisms of gene silencing by double-stranded RNA. Nature 2004, 431, 343-349. [CrossRef]

25. Sijen, T.; Fleenor, J.; Simmer, F.; Thijssen, K.L.; Parrish, S.; Timmons, L.; Plasterk, R.H.; Fire, A. On the role of RNA amplification in dsRNA-triggered gene silencing. Cell 2001, 107, 465-476. [CrossRef]

26. Taning, C.N.T.; Andrade, E.C.; Hunter, W.B.; Christiaens, O.; Smagghe, G. Asian citrus psyllid RNAi pathway-RNAi evidence. Sci. Rep. 2016, 6, 1-10. [CrossRef] [PubMed]

27. Ivashuta, S.; Zhang, Y.; Wiggins, B.E.; Ramaseshadri, P.; Segers, G.C.; Johnson, S.; Meyer, S.E.; Kerstetter, R.A.; McNulty, B.C.; Bolognesi, R.; et al. Environmental RNAi in herbivorous insects. RNA 2015, 21, 840-850. [CrossRef]

28. Winston, W.M.; Sutherlin, M.; Wright, A.J.; Feinberg, E.H.; Hunter, C.P. Caenorhabditis elegans SID-2 is required for environmental RNA interference. Proc. Natl. Acad. Sci. USA 2007, 104, 10565-10570. [CrossRef]

29. Feinberg, E.H.; Hunter, C.P. Transport of dsRNA into cells by the transmembrane protein SID-1. Science. 2003, 301, 1545-1547. [CrossRef]

30. Shih, J.D.; Hunter, C.P. SID-1 is a dsRNA-selective dsRNA-gated channel. RNA 2011, 1057-1065. [CrossRef]

31. Cooper, A.M.W.; Silver, K.; Zhang, J.; Park, Y.; Zhu, K.Y. Molecular mechanisms influencing efficiency of RNA interference in insects. Pest Manag. Sci. 2019, 75, 18-28. [CrossRef]

32. Winston, W.M.; Molodowitch, C.; Hunter, C.P. Systemic RNAi in C. elegans requires the putative transmembrane protein SID-1. Science 2002, 295, 2456-2459. [CrossRef] [PubMed]

33. $\mathrm{Xu}, \mathrm{W}$; Han, Z. Cloning and phylogenetic analysis of SID-1-like genes from aphids. J. Insect Sci. 2008, 8, 1-6. [CrossRef] [PubMed]

34. Xiao, D.; Gao, X.; Xu, J.; Liang, X.; Li, Q.; Yao, J.; Zhu, K.Y. Clathrin-dependent endocytosis plays a predominant role in cellular uptake of double-stranded RNA in the red flour beetle. Insect Biochem. Mol. Biol. 2015, 60, 68-77. [CrossRef] [PubMed]

35. Jain, R.G.; Robinson, K.E.; Asgari, S.; Mitter, N. Current scenario of RNAi-based hemipteran control. Pest Manag. Sci. 2021, 77, 2188-2196. [CrossRef]

36. Joga, M.R.; Zotti, M.J.; Smagghe, G.; Christiaens, O. RNAi efficiency, systemic properties, and novel delivery methods for pest insect control: What we know so far. Front. Physiol. 2016, 7, 1-14. [CrossRef]

37. El-Shesheny, I.; Hijaz, F.; El-Hawary, I.; Mesbah, I.; Killiny, N. Impact of different temperatures on survival and energy metabolism in the Asian citrus psyllid, Diaphorina citri Kuwayama. Comp. Biochem. Physiol. Part A Mol. Integr. Physiol. 2016, $192,28-37$. [CrossRef] [PubMed]

38. Santos-Ortega, Y.; Killiny, N. Silencing of sucrose hydrolase causes nymph mortality and disturbs adult osmotic homeostasis in Diaphorina citri (Hemiptera: Liviidae). Insect Biochem. Mol. Biol. 2018, 101, 131-143. [CrossRef]

39. Killiny, N.; Kishk, A. Delivery of dsRNA through topical feeding for RNA interference in the citrus sap piercing-sucking hemipteran, Diaphorina citri. Arch. Insect Biochem. Physiol. 2017, 95, 1-13. [CrossRef]

40. Zhu, Y.C.; Yao, J.; Luttrell, R. Identification of genes potentially responsible for extra-oral digestion and overcoming plant defense from salivary glands of the tarnished plant bug (Hemiptera: Miridae) using cDNA sequencing. J. Insect Sci. 2016, 16. [CrossRef]

41. Yu, X.; Gowda, S.; Killiny, N. Double-stranded RNA delivery through soaking mediates silencing of the muscle protein 20 and increases mortality to the Asian citrus psyllid, Diaphorina citri. Pest Manag. Sci. 2017, 73, 1846-1853. [CrossRef]

42. Yu, X.; Killiny, N. Effect of silencing a boule homologue on the survival and reproduction of Asian citrus psyllid Diaphorina citri. Physiol. Entomol. 2018, 43, 268-275. [CrossRef]

43. Liu, X.; Zou, Z.; Zhang, C.; Liu, X.; Wang, J.; Xin, T.; Xia, B. Knockdown of the trehalose-6-phosphate synthase gene using rna interference inhibits synthesis of trehalose and increases lethality rate in Asian citrus psyllid, Diaphorina citri (Hemiptera: Psyllidae). Insects 2020, 11, 605. [CrossRef]

44. Liu, X.Q.; Jiang, H.B.; Fan, J.Y.; Liu, T.Y.; Meng, L.W.; Liu, Y.; Yu, H.Z.; Dou, W.; Wang, J.J. An odorant-binding protein of Asian citrus psyllid, Diaphorina citri, participates in the response of host plant volatiles. Pest Manag. Sci. 2021. [CrossRef]

45. Ghosh, S.K.B.; Hunter, W.B.; Park, A.L.; Gundersen-Rindal, D.E. Double-stranded RNA oral delivery methods to induce RNA interference in phloem and plant-sap-feeding hemipteran insects. J. Vis. Exp. 2018, 135, 57390. [CrossRef]

46. Andrade, E.D.; Hunter, W.B. RNA Interference-Natural Gene-Based Technology for Highly Specific Pest Control (HiSPeC). In RNA Interference; Abdurakhmonov, I.Y., Ed.; IntechOpen: Rijeka, Croatia, 2016; pp. 391-409. ISBN 978-953-51-2272-2.

47. Arnosti, A.; Delalibera Jr, I.; Conceschi, M.R.; Travaglini, R.V.; Camargo-Mathias, M.I. Morphological mapping of the integument of adult females of Diaphorina citri Kuwayama, targeting the development of control strategies. Int. J. Adv. Agric. Res. 2016, 4, 57-64. [CrossRef] 
48. Silver, K.; Cooper, A.M.W.; Zhu, K.Y. Strategies for enhancing the efficiency of RNA interference in insects. Pest Manag. Sci. 2021. [CrossRef]

49. Christiaens, O.; Swevers, L.; Smagghe, G. DsRNA degradation in the pea aphid (Acyrthosiphon pisum) associated with lack of response in RNAi feeding and injection assay. Peptides 2014, 53, 307-314. [CrossRef] [PubMed]

50. Yu, X.D.; Liu, Z.C.; Huang, S.L.; Chen, Z.Q.; Sun, Y.W.; Duan, P.F.; Ma, Y.Z.; Xia, L.Q. RNAi-mediated plant protection against Aphids. Pest Manag. Sci. 2016, 72. [CrossRef] [PubMed]

51. Li, H.; Guan, R.; Guo, H.; Miao, X. New insights into an RNAi approach for plant defence against piercing-sucking and stem-borer insect pests. Plant Cell Environ. 2015, 38, 2277-2285. [CrossRef] [PubMed]

52. Li, H.; Khajuria, C.; Rangasamy, M.; Gandra, P.; Fitter, M.; Geng, C.; Woosely, A.; Hasler, J.; Schulenberg, G.; Worden, S.; et al. Long dsRNA but not siRNA initiates RNAi in western corn rootworm larvae and adults. J. Appl. Entomol. 2015, 139, 432-445. [CrossRef]

53. El-Shesheny, I.; Hajeri, S.; El-Hawary, I.; Gowda, S.; Killiny, N. Silencing abnormal wing disc gene of the Asian citrus psyllid, Diaphorina citri disrupts adult wing development and increases nymph mortality. PLoS ONE 2013, 8, e65392. [CrossRef]

54. Killiny, N.; Hajeri, S.; Tiwari, S.; Gowda, S.; Stelinski, L.L. Double-stranded RNA uptake through topical application, mediates silencing of five CYP4 genes and suppresses insecticide resistance in Diaphorina citri. PLoS ONE 2014, 9, e110536. [CrossRef]

55. Galdeano, D.M.; Breton, M.C.; Lopes, J.R.S.; Falk, B.W.; Machado, M.A. Oral delivery of double-stranded RNAs induces mortality in nymphs and adults of the Asian citrus psyllid, Diaphorina citri. PLoS ONE 2017, 12, e0171847. [CrossRef] [PubMed]

56. Kishk, A.; Hijaz, F.; Anber, H.A.I.; AbdEl-Raof, T.K.; El-Sherbeni, A.E.H.D.; Hamed, S.; Killiny, N. RNA Interference of Acetylcholinesterase in the Asian Citrus Psyllid, Diaphorina citri, Increases its Susceptibility to Carbamate and Organophosphate Insecticides; Elsevier Inc.: Amsterdam, The Netherlands, 2017; Volume 143, ISBN 1863956883.

57. Angelotti-Mendonça, J.; Bassan, M.M.; Marques, J.P.R.; Yamamoto, P.T.; Figueira, A.; Piedade, S.M.D.S.; Mourão Filho, F.A.A Knockdown of calreticulin, laccase, and snf7 genes through RNAi is not effective to control the Asian citrus psyllid (Hemiptera: Livideae). J. Econ. Entomol. 2020, 113, 2931-2940. [CrossRef]

58. Hunter, W.B.; Sinisterra-Hunter, X.H. Emerging RNA Suppression Technologies to Protect Citrus Trees from Citrus Greening Disease Bacteria, 1st ed.; Elsevier Ltd.: Amsterdam, The Netherlands, 2018; Volume 55, ISBN 9780128150795.

59. Bennett, M.; Deikman, J.; Hendrix, B.; Iandolino, A. Barriers to efficient foliar uptake of dsRNA and molecular barriers to dsRNA activity in plant cells. Front. Plant Sci. 2020, 11, 816. [CrossRef]

60. Dias, N.P.; Cagliari, D.; dos Santos, E.A.; Smagghe, G.; Jurat-Fuentes, J.L.; Mishra, S.; Nava, D.E.; Zotti, M.J. Insecticidal gene silencing by RNAi in the neotropical region. Neotrop. Entomol. 2020, 49, 1-11. [CrossRef] [PubMed]

61. Yan, S.; Ren, B.Y.; Shen, J. Nanoparticle-mediated double-stranded RNA delivery system: A promising approach for sustainable pest management. Insect Sci. 2021, 28, 21-34. [CrossRef]

62. Karny, A.; Zinger, A.; Kajal, A.; Shainsky-Roitman, J.; Schroeder, A. Therapeutic nanoparticles penetrate leaves and deliver nutrients to agricultural crops. Sci. Rep. 2018, 8, 1-10. [CrossRef]

63. Pugsley, C.E.; Isaac, R.E.; Warren, N.J.; Cayre, O.J. Recent advances in engineered nanoparticles for RNAi-mediated crop protection against insect pests. Front. Agron. 2021, 3, 9. [CrossRef]

64. Wang, X.; Feng, Y.; Dong, P.; Huang, J. A mini review on carbon quantum dots: Preparation, properties, and electrocatalytic application. Front. Chem. 2019, 7, 671. [CrossRef]

65. Dziewięcka, M.; Pawlyta, M.; Majchrzycki, Ł.; Balin, K.; Barteczko, S.; Czerkawska, M.; Augustyniak, M. The structureproperties—cytotoxicity interplay: A crucial pathway to determining graphene oxide biocompatibility. Int. J. Mol. Sci. 2021, 22, 5401. [CrossRef]

66. Laisney, J.; Loczenski Rose, V.; Watters, K.; Donohue, K.V.; Unrine, J.M. Delivery of short hairpin RNA in the neotropical brown stink bug, Euschistus heros, using a composite nanomaterial. Pestic. Biochem. Physiol. 2021, 177, 104906. [CrossRef]

67. Christiaens, O.; Whyard, S.; Vélez, A.M.; Smagghe, G. Double-stranded RNA technology to control insect pests: Current status and challenges. Front. Plant Sci. 2020, 11, 451. [CrossRef]

68. Neumeier, J.; Meister, G. siRNA Specificity: RNAi mechanisms and strategies to reduce off-target effects. Front. Plant Sci. 2021, 11, 2196. [CrossRef]

69. Hannus, M.; Beitzinger, M.; Engelmann, J.C.; Weickert, M.T.; Spang, R.; Hannus, S.; Meister, G. SiPools: Highly complex but accurately defined siRNA pools eliminate off-target effects. Nucleic Acids Res. 2014, 42, 8049-8061. [CrossRef] [PubMed]

70. Wytinck, N.; Manchur, C.L.; Li, V.H.; Whyard, S.; Belmonte, M.F. DsRNA uptake in plant pests and pathogens: Insights into RNAi-based insect and fungal control technology. Plants 2020, 9, 1780. [CrossRef]

71. Chhipa, H. Nanofertilizers and nanopesticides for agriculture. Environ. Chem. Lett. 2017, 15, 15-22. [CrossRef]

72. Agrawal, N.; Dasaradhi, P.V.N.; Mohmmed, A.; Malhotra, P.; Bhatnagar, R.K.; Mukherjee, S.K. RNA interference: Biology, mechanism, and applications. Microbiol. Mol. Biol. Rev. 2003, 67, 657-685. [CrossRef] [PubMed]

73. Vélez, A.M.; Fishilevich, E. The mysteries of insect RNAi: A focus on dsRNA uptake and transport. Pestic. Biochem. Physiol. 2018, 151, 25-31. [CrossRef]

74. Pampolini, F.; Rieske, L.K. Emerald Ash borer specific gene silencing has no effect on non-target organisms. Front. Agron. 2020, 2, 1-11. [CrossRef]

75. Lück, S.; Kreszies, T.; Strickert, M.; Schweizer, P.; Kuhlmann, M.; Douchkov, D. siRNA-Finder (si-Fi) Software for RNAi-target design and off-target prediction. Front. Plant Sci. 2019, 10, 1023. [CrossRef] [PubMed] 
76. Mendelsohn, M.L.; Gathmann, A.; Kardassi, D.; Sachana, M.; Hopwood, E.M.; Dietz-Pfeilstetter, A.; Michelsen-Correa, S.; Fletcher, S.J.; Székács, A. Summary of discussions from the 2019 OECD conference on RNAi based pesticides. Front. Plant Sci. 2020, 11, 740. [CrossRef]

77. Rodrigues, T.B.; Petrick, J.S. Safety considerations for humans and other vertebrates regarding agricultural uses of externally applied RNA molecules. Front. Plant Sci. 2020, 11, 407. [CrossRef] [PubMed]

78. Mezzetti, B.; Smagghe, G.; Arpaia, S.; Christiaens, O.; Dietz-Pfeilstetter, A.; Jones, H.; Kostov, K.; Sabbadini, S.; Opsahl-Sorteberg, H.G.; Ventura, V.; et al. RNAi: What is its position in agriculture? J. Pest Sci. 2020, 93, 1125-1130. [CrossRef]

79. Baum, J.A.; Bogaert, T.; Clinton, W.; Heck, G.R.; Feldmann, P.; Ilagan, O.; Johnson, S.; Plaetinck, G.; Munyikwa, T.; Pleau, M.; et al. Control of coleopteran insect pests through RNA interference. Nat. Biotechnol. 2007, 25, 1322-1326. [CrossRef] [PubMed]

80. Mao, Y.B.; Cai, W.J.; Wang, J.W.; Hong, G.J.; Tao, X.Y.; Wang, L.J.; Huang, Y.P.; Chen, X.Y. Silencing a cotton bollworm P450 monooxygenase gene by plant-mediated RNAi impairs larval tolerance of gossypol. Nat. Biotechnol. 2007, 25, 1307-1313. [CrossRef]

81. Koci, J.; Ramaseshadri, P.; Bolognesi, R.; Segers, G.; Flannagan, R.; Park, Y. Ultrastructural changes caused by Snf7 RNAi in larval enterocytes of western corn rootworm (Diabrotica virgifera virgifera Le Conte). PLoS ONE 2014, 9, e83985. [CrossRef] [PubMed]

82. Sharma, R.; Christiaens, O.; Taning, C.N.T.; Smagghe, G. RNAi-mediated mortality in southern green stinkbug Nezara viridula by oral delivery of dsRNA. Pest Manag. Sci. 2021, 77, 77-84. [CrossRef]

83. Castellanos, N.L.; Smagghe, G.; Sharma, R.; Oliveira, E.E.; Christiaens, O. Liposome encapsulation and EDTA formulation of dsRNA targeting essential genes increase oral RNAi-caused mortality in the Neotropical stink bug Euschistus heros. Pest Manag. Sci. 2019, 75, 537-548. [CrossRef] [PubMed]

84. Abdellatef, E. Tuning beforehand: A foresight on RNA interference (RNAi) and in vitro-derived dsRNAs to enhance crop resilience to biotic and abiotic stresses. Mol. Sci. 2021, 22, 7687. [CrossRef] [PubMed]

85. Hall, D.G.; Richardson, M.L.; Ammar, E.D.; Halbert, S.E. Asian citrus psyllid, Diaphorina citri, vector of citrus Huanglongbing disease. Entomol. Exp. Appl. 2013, 146, 207-223. [CrossRef]

86. Guo, S.H.; Liu, Y.M.; Wang, Z.Y.; Wang, F.F.; Mao, Y.K.; Hu, Y.W.; Han, P.; Cuthbertson, A.G.S.; Qiu, B.L.; Sang, W. Transcriptome analysis reveals TOR signalling-mediated plant flush shoots governing Diaphorina citri Kuwayama oviposition. Insect. Mol. Biol. 2021, 30, 264-276. [CrossRef] [PubMed]

87. Cagliari, D.; Avila dos Santos, E.; Dias, N.; Smagghe, G.; Zotti, M. Nontransformative strategies for RNAi in crop protection. Modul. Gene Expr.-Abridging RNAi Cris. Technol. 2019. [CrossRef]

88. Dietz-Pfeilstetter, A.; Mendelsohn, M.; Gathmann, A.; Klinkenbuß, D. Considerations and regulatory approaches in the USA and in the EU for dsRNA-based externally applied pesticides for plant protection. Front. Plant Sci. 2021, 12, 682387. [CrossRef] [PubMed]

89. Campos, H. The Innovation Revolution in Agriculture; Springer: Cham, Switzerland, 2021; ISBN 9783030509903. 